\title{
Scientometric Dimensions of Knowledge Management Research in India: A Study based on Scopus database
}

\author{
Surulinathi $M^{*}$ \\ surulinathi@gmail.com \\ Amsaveni ${ }^{*}$ \\ veni032002@gmail.com \\ Maheswaran $\mathrm{K}^{*}$ \\ karuppiah.maheswaran@gmail.com \\ S.Srinivasaraghavan** \\ maduraiseenoo@yahoo.co.in
}

\begin{abstract}
This paper attempts to analyse quantitatively the growth and development of Knowledge Management Research in India in terms of publication output as reflected in Scopus database. During 1999-2007 a total of 51 papers were published by the Knowledge Management researchers to various domains: Business, Management and Accounting (24), Engineering (18), Social Sciences (7), Computer Science (6), Decision Sciences (6), Multidisciplinary (4), Mathematics (3), Environmental Science (2), Agricultural and Biological Sciences (1), Earth and Planetary Sciences (1), Economics, Econometrics and Finance (1), Materials Science (1). Year-wise growth of publications and input of records to Scopus database by India is analyzed. More than 80 percent of publications were published in journals. The most preferred journals were International Journal of Information Technology and Management (7), Journal of Scientific and Industrial Research (4), Electronic Library (2), Human Systems Management (2), Journal of Knowledge Management (2), International Journal of Technology Management (2), International Conference on Information and Knowledge Management Proceedings (2), Proceedings Frontiers in Education Conference (2), others journals each (1). There were as many as 24 (47.06) papers contributed by single author. There were five authors contributions is zero and more than 5 authors contribution is less than 1(1.96). The publication behavior indicates that the Knowledge management researchers were lowly selective in publishing.
\end{abstract}

KEYWORDS: Knowledge Management in India; Mind Map; Scientometric analysis; Authorship pattern; Subject Domain; Free mind Knowledge Mapping Software

\footnotetext{
${ }^{*}$ Ph.D Research Scholars, DLIS, Annamalai University, Chidambaram-2

${ }^{* *}$ Bharathidasan University, Tiruchirappalli, India
} 


\section{Introduction}

Scientometrics the branch science of science that describes the output traits in terms of organizational research structure, resource inputs and outputs, develops benchmarks to evaluate the quality of information output. Scientometric studies characterize the disciplines using the growth pattern and other attributes. These studies have potential particularly in assessing the emerging disciplines. In the present study, we did the scientometric mapping of knowledge management, a significantly growing area in the knowledge-driven world.

Mind mapping software helps to get beyond the limitations of thinking. The ability to arrange information from many sources in a logical order has become the most important factor for survival in this modern informational world. However, the brain has the ability to process visual information much more efficiently. The old linear pattern of thinking by reading and describing from left to right, top to bottom has many problems in organizing information coming from eyes, ears, etc. Therefore, the most essential, but also limited, ability to receive information and express your thoughts is to make a habit of extracting essential words and analyzing their co-relation.

New technologies have changed the way organizations view and use knowledge. Information can now be collected, analyzed and distributed in ways not previously possible. Databases help to collect, store, and filter and make sense of this information. Groupware allows communities of practice to grow beyond the limits of time and place. Network makes it possible to disseminate information to millions simultaneously. Electronic Performance Support Systems (EPSS) can be used to support cognitive skills and provide technical expertise.

However, it is not just the technology alone that is driving the excitement around Knowledge Management. Knowledge Management is exciting because it makes sense to executives. They know that there are rich resources nestled in the minds and hearts of their organizations. They want access to those resources and to hold onto them as the organization. Knowledge Management is planning, designing, building, operating and maintaining the knowledge management system. Knowledge management is managing the knowledge of

- Information in Document

-Sounds

-Images and

-Text

- Knowledge in People Heads

-Collaboration

-Storytelling

-Community of Practice

-Mind mapping

- Organizational Memory

-Knowledge Re-use

-Community of Practice

-Lesson Learning

- Conversion of Information to Knowledge

-Logical intelligence

-Collaborative Intelligence

-Sensory Experience

-Intuition 


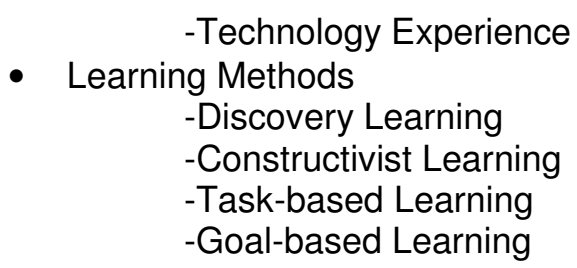

Knowledge management is, to a certain extent, the logical next step in a sequence of societal developments that has already been going on for a very long time. The likely future of knowledge management is explored along four perspectives: the management practices perspective, the information technology perspective, the organizational efforts perspective and the development, supply and adoption rate perspective [Wiig, 1997].

Thus, mapping of knowledge management has potential and enable the users to get an understanding the structure of it.

\section{Scope and Methodology}

The present study attempts to find out the publication pattern of Indian researchers in the field of knowledge management. The study is based on the references and aims to analyse quantitatively the growth and development of Knowledge Management in India in terms of publication output as reflected in Scopus database during years, 1999-2007. Scopus is the largest abstract and citation database of research literature and quality web-only journals. It's designed to enable not only the researchers for accessing scientific information but provide the information scientists to study the literature for different information analyses purposes. Quick, easy and comprehensive, Scopus provides superior support of the literature research process.

\section{Objectives of the Study}

The main objective of the study is to present the growth of literature and make the quantitative assessment of status of Knowledge management research in India by analyzing the various features. The specific objectives are -

- To measure the year-wise growth of publications in terms of input of records in Scopus database.

- To measure the domain-wise contributions

- To measure the authorship pattern in the publications

- To measure the Source of publications

- To measure the format of publications

\section{Method}

The records were downloaded from the online Scopus for the studied period. The records then were exported in to the basic dataset created for the study. Any scientometric mapping exercise requires a customized database structure so that analytical processing can be executed. 


\section{Results and Discussion}

\section{Author-wise Distribution}

Authorship pattern among Knowledge Management researchers is given in the Table 1 and Figure 1. Single authored papers contributions are high $24(47.06 \%)$. Two authored papers account for $16(31.37 \%)$ followed by three authored papers $7(13.73 \%)$, four authored papers $3(5.88 \%)$ and five-authored paper is nil and more than five authors paper is $1(1.96 \%)$. The author, Bowonder B has occupied the first rank in publications. It can be clearly visualized from the below Table 1 and Figure 1.

\section{Figure 1 - Author-wise distribution}

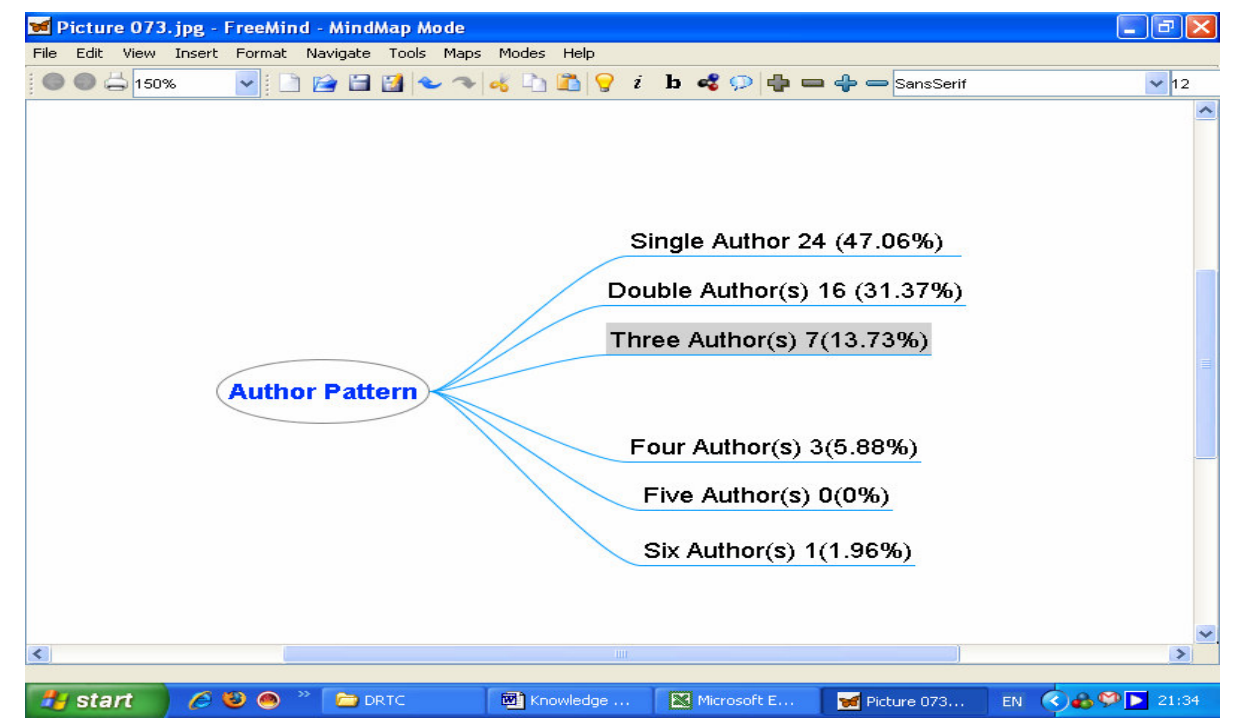

Table 1 - Author-wise distribution

\begin{tabular}{|l|c|c|c|c|}
\hline $\begin{array}{l}\text { Author wise } \\
\text { Pattern }\end{array}$ & $\begin{array}{l}\text { No of } \\
\text { Records }\end{array}$ & Percentage & Cumulative & $\begin{array}{l}\text { Cumulative } \\
\text { Percentage }\end{array}$ \\
\hline Single Author & 24 & 47.06 & 24 & 47.06 \\
\hline Double Author(s) & 16 & 31.37 & 40 & 78.43 \\
\hline Three Author(s) & 7 & 13.73 & 47 & 92.16 \\
\hline Four Author(s) & 3 & 5.88 & 50 & 98.04 \\
\hline Five Author(s) & 0 & 0.00 & 50 & 98.04 \\
\hline Six Author(s) & 1 & 1.96 & 51 & $\mathbf{1 0 0 . 0 0}$ \\
\hline Total & $\mathbf{5 1}$ & $\mathbf{1 0 0 . 0 0}$ & $\mathbf{5 1}$ & \\
\hline
\end{tabular}




\section{Year-wise Distribution}

During the 7 years period (1999-2007) India has produced a total of 51 publications. The highest number of publications was 11 in 2000. The average number of publications per year was 7.29. The lowest number of publication was 1 in 1999 because it was the first period of coverage of records (Table 2 and Figure 2). In 2007 also, the publication is very low because of the incomplete coverage and one can expect that the year 2007 may witness high productivity.

Figure 2 - Year-wise distribution

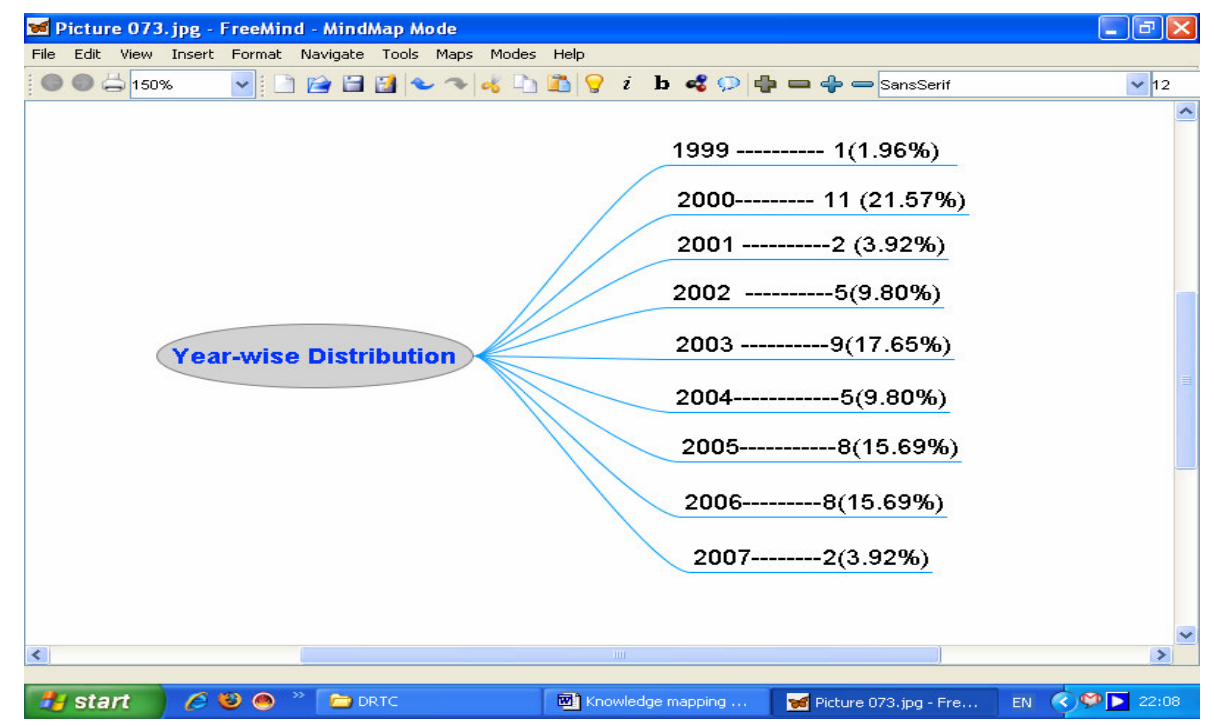

Table 2 - Year-wise distribution

$\begin{array}{ccc}\text { Year } & \begin{array}{c}\text { No of } \\ \text { Records }\end{array} & \text { Percentage } \\ 1999 & 1 & 1.96 \\ 2000 & 11 & 21.57 \\ 2001 & 2 & 3.92 \\ 2002 & 5 & 9.80 \\ 2003 & 9 & 17.65 \\ 2004 & 5 & 9.80 \\ 2005 & 8 & 15.69 \\ 2006 & 8 & 15.69 \\ 2007 & 2 & 3.92 \\ & \text { Total } & \mathbf{1 0 . 0 0}\end{array}$




\section{Document Type-wise Distribution}

During the 7 years period (1999-2007) India has produced a total of 51 publications. The highest number of publications were 41(80.39\%) Journal articles and other publications were (10) (19.61\%) reviews (Figure 3 and Table 3 )

Figure 3 - Document Type-wise Distribution

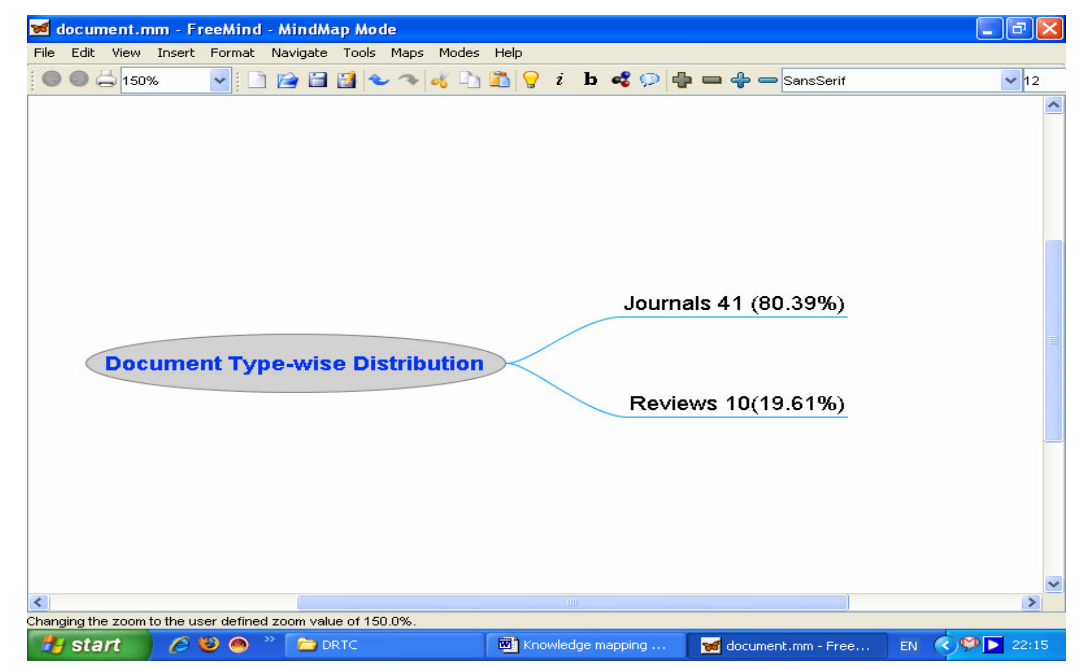

Table 3 - Document Type-wise Distribution

$\begin{array}{lcc}\text { Document Type } & \begin{array}{c}\text { No of } \\ \text { Records }\end{array} & \text { Percentage } \\ \text { Article (41) } & 41 & 80.39 \\ \text { Review (10) } & 10 & 19.61 \\ \text { Total } & \mathbf{5 1} & \mathbf{1 0 0 . 0 0}\end{array}$

\section{Subject Area-wise or Domain-wise Distribution}

During 7 years period (1999-2007) India has produced a total of 51 publications have contributed significantly to the following main domains which have been broadly grouped as:

- Business, Management and Accounting

- Engineering

- Social Sciences

- Computer Science

- Decision Sciences

- Multidisciplinary

- Mathematics

- Environmental Science

- Agricultural and Biological Sciences

- Earth and Planetary Sciences

- Economics, Econometrics and Finance 
- Materials Science

There were $24(32.43 \%)$ publications in 'Business, Management and Accounting' domain followed by 18 (24.32\%) in 'Engineering', 7 (9.46\%) publications in 'Social Sciences', 6 (8.11\%) publications in 'Computer Science and Decision Science', 4 $(5.41 \%)$ publications in 'Multidisciplinary', 3(4.05\%) publications in 'mathematics', $2(2.70 \%)$ publications in Environmental Science and 1(1.35\%) publication in 'Agricultural and Biological Sciences, Economics, Econometrics and Finance, and Materials Science'. Year-wise growth of publications in each domain is given below in Figure 4 and Table 4.

Figure 4 - Year-wise growth of publications

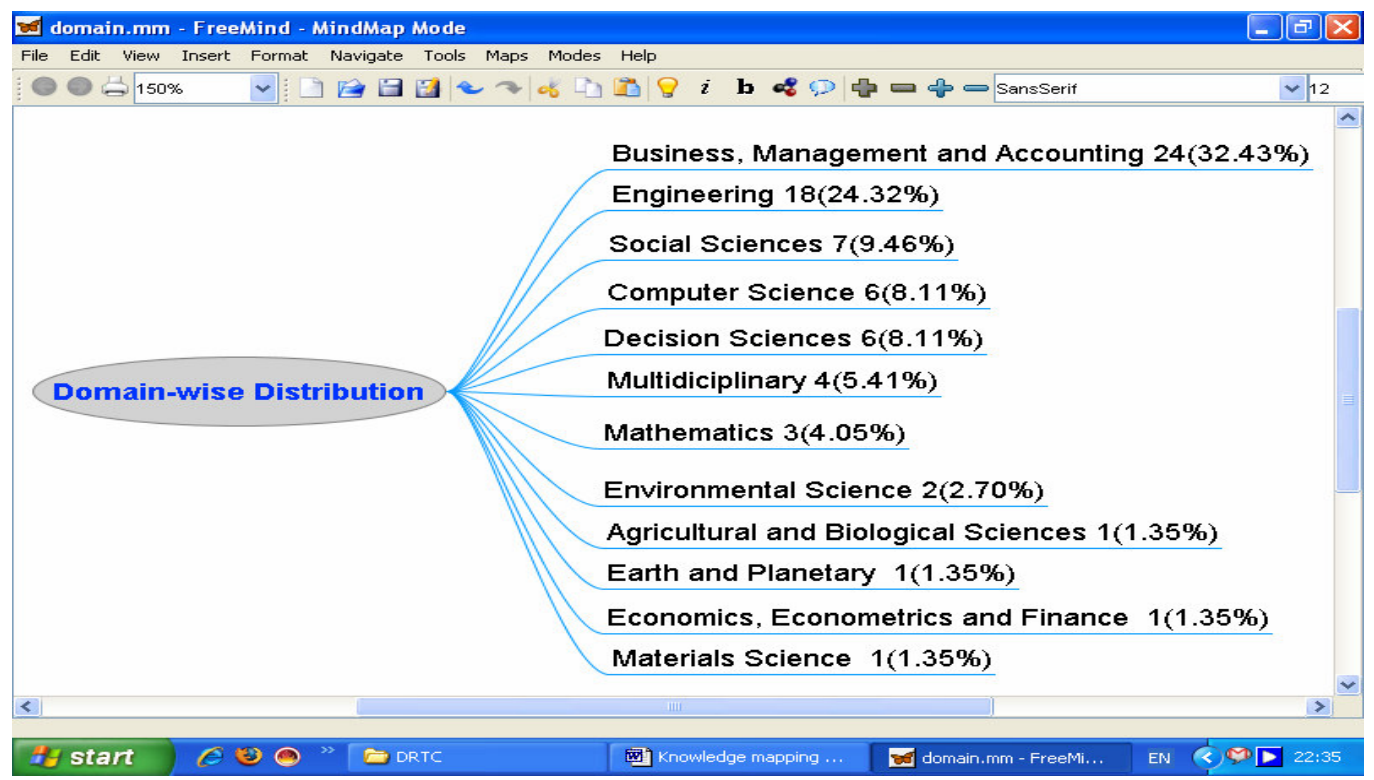

Table 4 - Year-wise growth of publications

\begin{tabular}{|c|c|c|}
\hline Subject Area & $\begin{array}{l}\text { No of } \\
\text { Records }\end{array}$ & Percentage \\
\hline $\begin{array}{l}\text { Business, Management } \\
\text { and Accounting }\end{array}$ & 24 & 32.43 \\
\hline Engineering & 18 & 24.32 \\
\hline Social Sciences & 7 & 9.46 \\
\hline Computer Science & 6 & 8.11 \\
\hline Decision Sciences & 6 & 8.11 \\
\hline Multidisciplinary & 4 & 5.41 \\
\hline Mathematics & 3 & 4.05 \\
\hline Environmental Science & 2 & 2.70 \\
\hline $\begin{array}{l}\text { Agricultural and Biological } \\
\text { Sciences }\end{array}$ & 1 & 1.35 \\
\hline $\begin{array}{l}\text { Earth and Planetary } \\
\text { Sciences }\end{array}$ & 1 & 1.35 \\
\hline $\begin{array}{l}\text { Economics, Econometrics } \\
\text { and Finance }\end{array}$ & 1 & 1.35 \\
\hline Materials Science & $\begin{array}{c}1 \\
74\end{array}$ & $\begin{array}{c}1.35 \\
100.00\end{array}$ \\
\hline
\end{tabular}




\section{Source-wise Distribution in the publications}

During the 7 years period (1999-2007), India has produced a total of 51 publications. More than $41(80.39 \%)$ the Knowledge Management research was published in journals and the rest was in reviews $10(19.61 \%)$. The highest number of publications was $7(13.73 \%)$ in International Journal of Information Technology and Management journal and $4(7.84 \%)$ followed by Journal of Scientific and Industrial Research and other journals having less than 2 publications.

\section{Figure 5 - Source-wise Distribution}

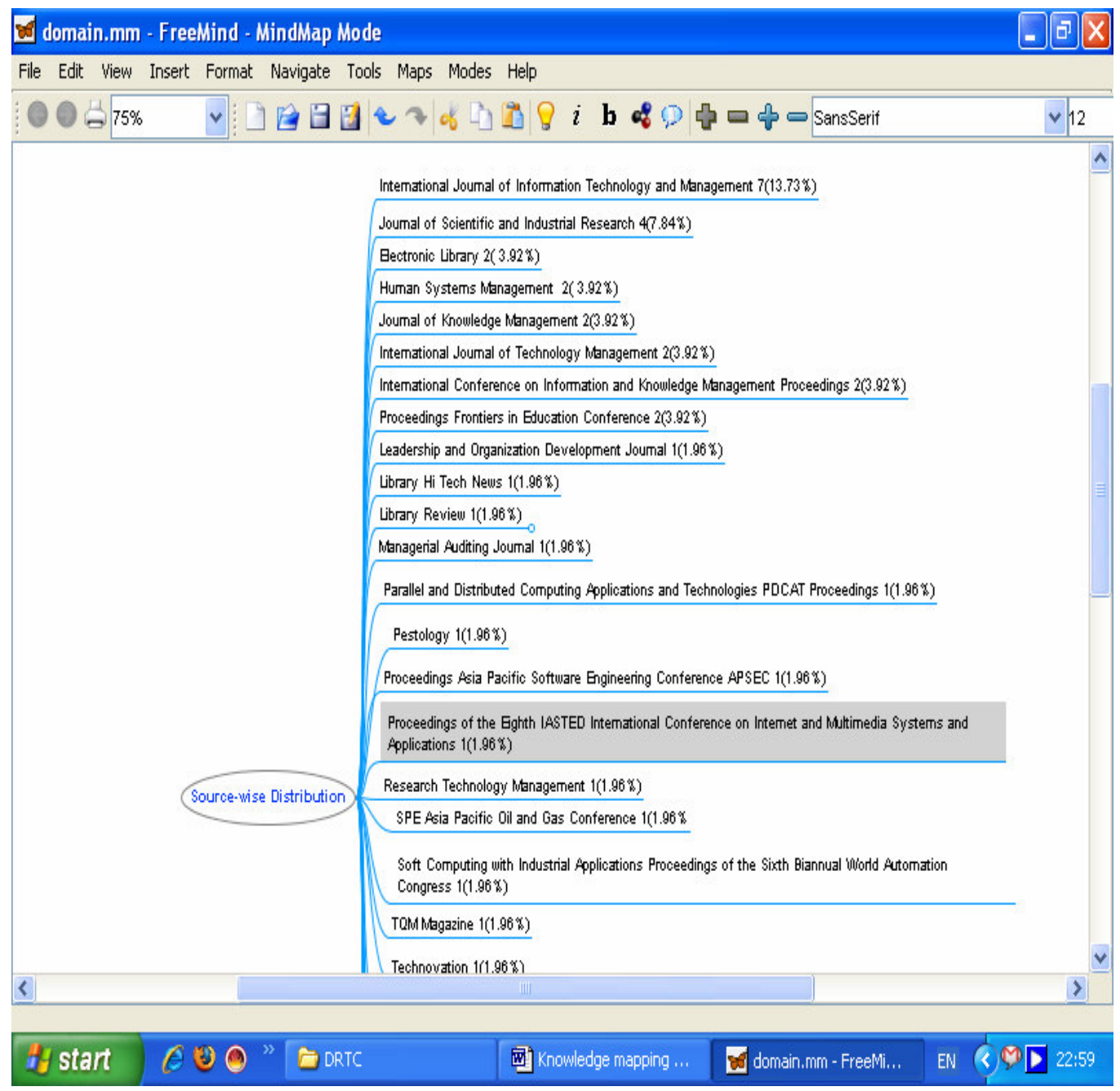


Table 5 - Source-wise Distribution

\begin{tabular}{|c|c|c|}
\hline Source Title & $\begin{array}{l}\text { No of } \\
\text { Records }\end{array}$ & Percentage \\
\hline $\begin{array}{l}\text { International Journal of Information Technology and } \\
\text { Management (7) }\end{array}$ & 7 & 13.73 \\
\hline Journal of Scientific and Industrial Research (4) & 4 & 7.84 \\
\hline Electronic Library (2) & 2 & 3.92 \\
\hline Human Systems Management (2) & 2 & 3.92 \\
\hline Journal of Knowledge Management (2) & 2 & 3.92 \\
\hline International Journal of Technology Management (2) & 2 & 3.92 \\
\hline $\begin{array}{l}\text { International Conference on Information and Knowledge } \\
\text { Management Proceedings (2) }\end{array}$ & 2 & 3.92 \\
\hline Proceedings Frontiers in Education Conference (2) & 2 & 3.92 \\
\hline Leadership and Organization Development Journal (1) & 1 & 1.96 \\
\hline Library Hi Tech News (1) & 1 & 1.96 \\
\hline Library Review (1) & 1 & 1.96 \\
\hline Managerial Auditing Journal (1) & 1 & 1.96 \\
\hline $\begin{array}{l}\text { Parallel and Distributed Computing Applications and } \\
\text { Technologies PDCAT Proceedings (1) }\end{array}$ & 1 & 1.96 \\
\hline Pestology (1) & 1 & 1.96 \\
\hline $\begin{array}{l}\text { Proceedings Asia Pacific Software Engineering Conference } \\
\text { APSEC (1) }\end{array}$ & 1 & 1.96 \\
\hline $\begin{array}{l}\text { Proceedings of the } 8^{\text {th }} \text { IASTED Inter. Conf. on Internet and } \\
\text { Multimedia Systems and Applications (1) }\end{array}$ & 1 & 1.96 \\
\hline Research Technology Management (1) & 1 & 1.96 \\
\hline SPE Asia Pacific Oil and Gas Conference (1) & 1 & 1.96 \\
\hline $\begin{array}{l}\text { Soft Computing with Industrial Applications Proceedings of } \\
\text { the Sixth Biannual World Automation Congress (1) }\end{array}$ & 1 & 1.96 \\
\hline TQM Magazine (1) & 1 & 1.96 \\
\hline Technovation (1) & 1 & 1.96 \\
\hline Knowledge and Information Systems (1) & 1 & 1.96 \\
\hline Journal of the Textile Association (1) & 1 & 1.96 \\
\hline Journal of Modern Applied Statistical Methods (1) & 1 & 1.96 \\
\hline Journal of Biological Systems (1) & 1 & 1.96 \\
\hline International Jrl of Operations and Production Mgmt (1) & 1 & 1.96 \\
\hline International Journal of Manufacturing Tech. and Mgmt(1) & 1 & 1.96 \\
\hline International Journal of Information Management (1) & 1 & 1.96 \\
\hline International Jrl. of Globalisation and Small Business (1) & 1 & 1.96 \\
\hline International Journal of Business Performance Mgmt (1) & 1 & 1.96 \\
\hline Information Technology Journal (1) & 1 & 1.96 \\
\hline Information Systems Management (1) & 1 & 1.96 \\
\hline $\begin{array}{l}\text { IETE Technical Review Institution of Electronics and } \\
\text { Telecommunication Engineers India (1) }\end{array}$ & 1 & 1.96 \\
\hline IEEE Software (1) & 1 & 1.96 \\
\hline Electronics Information and Planning (1) & 1 & 1.96 \\
\hline Annals of Cases on Information Technology (1) & 1 & 1.96 \\
\hline Total & 51 & 100.00 \\
\hline
\end{tabular}




\section{Conclusion}

This paper has highlighted quantitatively the contributions made by the Indian Knowledge Management researchers during 1999-2007 as reflected in Scopus database. During 7 years period (1999-2007) Indian contributions in terms of number of publications is not significant. A comparison of Indian output in relation to the world output may help in understanding the contribution in a better angle. Though the records available in the Scopus database reveal a small number, it is important that the Scopus covers only the peer-reviewed journals. If a broader coverage database is available, it may provide a reasonable number of papers. We suggest for tracking citation record of papers so that the impact of publications in knowledge management may be visible.

\section{Reference}

- Kademani, B.S. et al.(1994). Scientometric portrait of Noble Laureate Dr. C. V. Raman. Indian Journal of Information Library and Society 37(4),pp.215-49.(URL http://www.springerlink.com/content/892766tg4j133086/fulltext.pdf) Accessed on 26.7.2006.

- B. S. Kademani, Vijai Kumar, Anil Sagar and Anil Kumar. (2002) Scientometric Dimensions of Nuclear Science and Technology Research In India: A Study based on INIS (1970-2002) Database, Malaysian Journal of Library \& Information Science 11(1): pp. 23-48.

(URL http://eprints.rclis.org/archive/00007485/01/INIS MJLIS Final 1810 2006.pdf) Accessed on 20.10.2006.

- http://www.mindmapperusa.com/features.htm

- http://www.scopus.com 


\section{Appendix 1}

\section{Ranking of Individual Author}

\begin{tabular}{|l|c|c|}
\hline \multicolumn{1}{|c|}{ Author(s) } & No of Records & Ranking \\
\hline Bowonder, B. (3) & 3 & 1 \\
\hline Adak, S. (2) & 2 & 2 \\
\hline Miyake, T. (2) & 2 & 2 \\
\hline Rastogi, P.N. (2) & 2 & 2 \\
\hline Mohanty, R.P. (2) & 2 & 2 \\
\hline Saxena, A. (1) & 1 & 3 \\
\hline Satish, N.G. (1) & 1 & 3 \\
\hline Roy, P. (1) & 1 & 3 \\
\hline Ramasubramanian, S. (1) & 1 & 3 \\
\hline Raman, S. (1) & 1 & 3 \\
\hline Ramamritham, K. (1) & 1 & 3 \\
\hline Ramachandran, S. (1) & 1 & 3 \\
\hline Rajan, Y.S. (1) & 1 & 3 \\
\hline Prahlada, (1) & 1 & 3 \\
\hline Prabhakar, T.V. (1) & 1 & 3 \\
\hline Pillania, R.K. (1) & 1 & 3 \\
\hline Pandey, S.K. (1) & 1 & 3 \\
\hline Narain, R. (1) & 1 & 3 \\
\hline Murthy, P.N. (1) & 1 & 3 \\
\hline Mohania, M. (1) & 1 & 3 \\
\hline Misra, D.C. (1) & 1 & 3 \\
\hline Mishra, R.B. (1) & 1 & 3 \\
\hline Metri, B.A. (1) & 1 & 3 \\
\hline Yegneshwar, S. (1) & 1 & 3 \\
\hline Yadav, S. (1) & 1 & 3 \\
\hline Wasan, S.K. (1) & 1 & 3 \\
\hline Wadhwa, S. (1) & 1 & 3 \\
\hline Vanapalli, G.K. (1) & 1 & 3 \\
\hline Thangavel, K. (1) & 1 & 3 \\
\hline Tanweer, A. (1) & 1 & 3 \\
\hline Suresh, J.K. (1) & 1 & 3 \\
\hline Sukula, S.K. (1) & 1 & 3 \\
\hline Subramanian, K. (1) & 1 & 3 \\
\hline Srivatsa, S.K. (1) & 1 & 3 \\
\hline Srivastava, S.K. (1) & 1 & 3 \\
\hline Srivastava, B. (1) & 1 & 3 \\
\hline Sridhar, V. (1) & 1 & 3 \\
\hline So, J.C.F. (1) & 1 & 3 \\
\hline Sinha, M. (1) & 1 & 3 \\
\hline Singh, S.P. (1) & 1 & 3 \\
\hline Singh, M.D. (1) & 1 & 3 \\
\hline Sharma, S. (1) & 1 & 3 \\
\hline Shankar, R. (1) & 1 & 3 \\
\hline Saxena, A. (1) & 1 & 3 \\
\hline Girija, N. (1) & 1 & 3 \\
\hline Duddukuri, R. (1) & 1 & 3 \\
\hline Desouza, K.C. (1) & 1 & 3 \\
\hline Deshmukh, S.G. (1) & 1 & 3 \\
\hline Deka, M. (1) & 1 & 3 \\
\hline & 1 & 3 \\
\hline & 1 & 3 \\
\hline
\end{tabular}




\begin{tabular}{|l|l|l|}
\hline Dayasindhu, N. (1) & 1 & 3 \\
\hline Datta, A. (1) & 1 & 3 \\
\hline Choudhury, S.R. (1) & 1 & 3 \\
\hline Chandrakar, R. (1) & 1 & 3 \\
\hline Chandra, H. (1) & 1 & 3 \\
\hline Bolloju, N. (1) & 1 & 3 \\
\hline Bhunia, C.T. (1) & 1 & 3 \\
\hline Bhatnagar, V. (1) & 1 & 3 \\
\hline Bhatnagar, G. (1) & 1 & 3 \\
\hline Bhatia, S. (1) & 1 & 3 \\
\hline Bhardwaj, K.K. (1) & 1 & 3 \\
\hline Bhardwaj, D.N. (1) & 1 & 3 \\
\hline Batra, V.S. (1) & 1 & 3 \\
\hline Bamba, B. (1) & 1 & 3 \\
\hline Antony, J. (1) & 1 & 3 \\
\hline Ananpara, A. (1) & 1 & 3 \\
\hline Manjunath, U. (1) & 1 & 3 \\
\hline Mahapatra, T. (1) & 1 & 3 \\
\hline Mahanti, R. (1) & 1 & 3 \\
\hline Lakshman, C. (1) & 1 & 3 \\
\hline Kurnekar, M.P. (1) & 1 & 3 \\
\hline Kumar, P. (1) & 1 & 3 \\
\hline Kumar, D.A. (1) & 1 & 3 \\
\hline Kumar, B.S. (1) & 1 & 3 \\
\hline Kumar, A. (1) & 1 & 3 \\
\hline Kumar, A. (1) & 1 & 3 \\
\hline Kochikar, V.P. (1) & 1 & 3 \\
\hline Kochikar, V.P. (1) & 1 & 3 \\
\hline Khaneja, M. (1) & 1 & 3 \\
\hline Kankar, P. (1) & 1 & 3 \\
\hline Kammanahalli, H. (1) & 1 & 3 \\
\hline Kamesam, P.V. (1) & 1 & 3 \\
\hline Jagadeesan, G. (1) & 1 & 3 \\
\hline Hariharan, R. (1) & 1 & 3 \\
\hline Hanchate, S. (1) & 1 & 3 \\
\hline Haas, R. (1) & 1 & 3 \\
\hline Gupta, S.K. (1) & 1 & 3 \\
\hline Gopalan, S. (1) & 1 & 3 \\
\hline & 1 & 3 \\
\hline
\end{tabular}

